\title{
Det groteska och öppenhetens poetik i Bo Carpelans roman Benjamins bok
}

Bo Carpelans (I926-20Ii) litTerära produktion har inte förut undersökts ur groteskens synvinkel. Begreppet grotesk förekommer alltså inte i den tidigare forskningen och litteraturhistorieskrivningen kring författarskapet. I tidigare studier behandlas emellertid andra fenomen som ligger nära det groteska. En "mörkt leende humor" har uppfattats som karakteristisk för den carpelanska världen ${ }^{1}$ och författarens sätt att beskriva det förflutna har också beskrivits som mycket mörkt. ${ }^{2}$ Därtill har huvudpersonens marginalitet eller främlingskap uppfattats som en gemensam nämnare för Carpelans sena romaner. ${ }^{3}$ I den här artikeln studerar jag de groteska dragen i Bo Carpelans roman Benjamins bok (1997) ${ }^{4}$ med utgångspunkt i följande forskningsfrågor: I) Hur är det groteska uppbyggt i romanen Benjamins bok? och 2) Hur hänger verkets groteska drag ihop med den öppenhetens poetik som är central för Carpelans författarskap? I artikeln visar jag att det groteska är en central referensram för tolkningen av Benjamins bok, som samtidigt möjliggör en mera specifik granskning av de ovannämnda nyanserna. Det groteska är ställvis fördolt i verket, ställvis kommer det däremot explicit till uttryck genom metaforer och gestalter som bygger på groteskens tradition.

I. Thomas Warburton, Ättio år finlandssvensk litteratur, Helsingfors: Schildts I984, s. 37 I.

2. Anna Hollsten, Ei kattoa, ei seiniä. Näkökulmia Bo Carpelanin kirjallisuuskäsitykseen, Helsinki: Suomalaisen Kirjallisuuden Seura 2004, s. 274.

3. Michel Ekman \& Pia Ingström, "Prosa: bred epik och nyanserad novellkonst", Michel Ekman (red.), Finlands svenska litteratur 1900-20I2, Helsingfors: Svenska litteratursällskapet i Finland 20I4, s. 284.

4. Bo Carpelan, Benjamins bok, Helsingfors: Schildts 1997. 
Benjamins bok skildrar en resa som jagberättaren Benjamin gör till sin barndom, såväl konkret genom att besöka sin barndoms landskap som i sina minnen och sin fantasi. I dagboksliknande anteckningar söker den pensionerade översättaren sin identitet och strävar efter att lösa upp knutar i sitt förflutna: "Var dag skall jag försöka tolka mitt liv. Jag skall översätta min vardag. Jag skall ta till vara vad det stumma eller tysta säger." ${ }^{5}$ Upplägget är på många sätt typiskt för Carpelans prosa: en manlig jagberättare reflekterar över sitt förflutna och sitt åldrande, samtidigt som han rycks med och återupplever händelser och sinnesförnimmelser ur sin barndom. Därtill har verket en traumatisk aspekt som hänger ihop med skuldkänsla och en subjektiv upplevelse av kriget. Det traumatiska kommer till uttryck också i berättelsestrukturen i form av upprepningar och avbrott. ${ }^{6} \mathrm{I}$ min analys fokuserar jag på hur jagberättarens subjektiva upplevelse kommer till uttryck på en bildlig nivå, i form av groteska drag och i synnerhet genom en grotesk fågelgestalt med namnet Otaoli.

Ett centralt begrepp i Bo Carpelans essäistisk är öppenhet, som utgör ett kännetecken och ideal för den livskraftiga poesin. ${ }^{7}$ I en av sina poetiska essäer definierar Carpelan begreppet i relation till poeten John Keats' (I795-I82I) idé om den negativa förmågan, den kreativa människans förmåga att vila i osäkerheten. Med grund i denna uppfattning frigör sig den carpelanska öppenhetens poetik från ett tänkande som baserar sig på tydligt avgränsade kategorier och heltäckande svar. Öppenheten uppfattas i stället som en förmåga att betrakta och reflektera över livets motsättningar. Där ingår också ett ifrågasättande av gränserna och hierarkierna mellan olika kategorier, såsom mellan det förflutna, nuet och framtiden. ${ }^{8}$ Begreppet öppen-

5. Bo Carpelan, Benjamins bok, s. 9 .

6. Se t.ex. Anne Whitehead, Trauma fiction, Edinburgh: Edinburgh University Press 2004, s. 3. Enligt Whitehead kan trauma skildras på ett träffande sätt i fiktion endast genom att man efterbildar dess symptom, till exempel genom upprepning samt genom att det tidsmässiga och kronologiska bryts sönder.

7. Hollsten, Ei kattoa, ei seiniä, s. 87. I sin avhandling hänvisar Hollsten till Carpelans litteratursyn med begreppet öppenhetens poetik (fi. "avonaisuuden poetiikka"). Senare används begreppet också av Jan Hellgren, Bo Carpelan. Rummets diktare, Helsingfors: Svenska litteratursällskapet i Finland 2014.

8. Bo Carpelan, "Om diktens öppenhet", Hufvudstadsbladet 27/9 I960 (Den lectio praecursoria som Carpelan höll vid sin disputation). Enligt Hollsten, Ei kattoa, ei seiniä, s. 20, kan denna essä ses som en nyckeltext där Carpelan formulerar sin poetik. 
het är en kulminationspunkt i Carpelans mångsidiga poetik. Som en syntes av olika influenser kan öppenheten komma till uttryck på varierande sätt i författarens produktion. ${ }^{9} \mathrm{I}$ denna artikel ligger fokus på hur det groteska i Benjamins bok hänger ihop med öppenhetens poetik, samt hur detta kommer till uttryck genom ett uppbrytande av olika slags motsatsförhållanden.

I konsten kommer det groteska till uttryck till exempel genom en kombination av det frånstötande och det attraktiva, det komiska och det tragiska, eller det uppsluppna och det fasansfulla. Denna spänning mellan motsatta element kan ses som en gemensam nämnare för groteskforskningens heterogena fält och kanske som den mest centrala definierande egenskapen hos det groteska. ${ }^{10}$ Utöver dessa spänningar lyfter grotesken fram livets irrationella sida, det som trängts undan eller annars uttrycker utanförskap eller något avvikande. Enligt Justin D. Edwards och Rune Graulund är ett av de tre centrala dragen hos det groteska - drag som även kommer till uttryck i Benjamins bok - hybriditet, transgression och konstant rörelse. ${ }^{11}$ Mera konkret kan man, i enlighet med Shung-Liang Chao, uppfatta det groteska som ett konstnärligt modus, ett modus som i litteraturen särskilt kommer till uttryck i visuellt frapperande och skrämmande bilder. ${ }^{12}$ Den groteska bilden kan, som Frances S. Connelly fört fram, bygga på föränderlighet, betona det avvikande eller kombinera element som vanligen inte hör ihop. ${ }^{13}$

I Michail Bachtins och Wolfgang Kaysers klassiska studier, som influerat den färskaste forskningen i det groteska, har författarna identifierat drag som kännetecknar bildspråket, motiven och de typiska

9. Hollsten, Ei kattoa, ei seiniä, s. 287-294. Se också Hellgren, Bo Carpelan, s. 73-76.

Io. Dieter Meindl, American Fiction and the Metaphysics of the Grotesque, Missouri: University of Missouri Press I996, s. I4.

II. Justin D. Edwards \& Rune Graulund, Grotesque: The Nerw Critical Idiom, London \& New York: Routledge 20I3, s. I5.

I2. Shun-Liang Chao, Rethinking the Concept of the Grotesque. Crashaw, Baudelaire, Magritte, London: Modern Humanities Research Association and Maney Publishing 20Io, s. 7 .

13. Frances S. Connelly, The Grotesque in Western Art and Culture. The Image at Play, Cambridge: Cambridge University Press 2012, s. 2. Med sitt bildbegrepp syftar Connelly i huvudsak på framställningar inom bildkonsten, men begreppet kan tillämpas också i analys av språkligt gestaltade föreställningar och språkets bildlighet. 
gestalterna i grotesken. Dessa beskrivningar kommer jag att utnyttja i min analys. I Kaysers teori betonas den subjektiva och skräckinjagande sidan hos det groteska. ${ }^{14}$ Det subjektiva groteska hänger ihop med individens inåtvända psyke samt med en upplevelse av det besynnerliga eller främmande ("unheimlich", "uncanny") och det fasansfulla. ${ }^{15}$ Bachtin betonar däremot det offentliga, karnevalistiska och skrattretande i det groteska. ${ }^{16}$ Ur denna synvinkel har det groteska en positiv och förnyande karaktär. ${ }^{17}$

I artikeln kommer jag först att diskutera det groteskas roll i beskrivningen av jagberättarens subjektiva upplevelse. Därefter övergår jag till att analysera fågeln Otaoli, i samband med vilken det groteska alltid betonas. I därpå följande avsnitt lyfter jag fram de karnevalistiska dragen i verket, och de drag som ger upphov till ambivalens. Därefter fäster jag uppmärksamhet vid den metamorfos som Otaoli genomgår, för att sedan sammanfattningsvis granska hur det groteska har en koppling till öppenhetens poetik.

\section{DET GROTESKA SOM BESKRIVNING AV DET SUBJEKTIVA}

Jagberättaren i Benjamins bok drivs att gå igenom sitt förflutna efter en uppmaning han fătt i en dröm, en uppmaning som i romanen är formulerad på finska"Ota Olli pitkä reissu"(sv. Olli, gör en lång resa). ${ }^{18}$ Denna mening, som har sina rötter i Benjamins undermedvetna, har en anknytning till hans barndomsvän Olli. En sommardag håller Olli på att drunkna och får ett bestående handikapp. Som barn tolkar Benjamin händelsen så att han själv är skyldig till Ollis handikapp, eftersom olyckan föregåtts av en konfliktsituation mellan Benjamin och Olli, som ofta retats med sin kamrat. Bråket mellan vännerna tar slut då Benjamin, som varit i underläge, agerar aktivt: "Ollis lugg står

\footnotetext{
I4. Wolfgang Kayser, The Grotesque in Art and Literature, New York: Columbia University Press I963 [1957].

I5. Irma Perttula, Groteski suomalaisessa kirjallisuudessa. Neljä tapaustutkimusta, Helsinki: Suomalaisen Kirjallisuuden Seura 2010, s. 28-30.

16. Michail Bachtin, Rabelais och skrattets historia. François Rabelais'verk och den folkliga kulturen under medeltiden och renässansen, Gråbo: Anthropos I986 [I965].

17. Perttula, Groteski suomalaisessa kirjallisuudessa, s. 28.

I8. Carpelan, Benjamins bok, s. Io.
} 
på ända, han kommer tätt inpå, och då slår jag." ${ }^{19}$ Då Benjamin vänder sig om och går ifrån Olli, upplever han att han vänder ryggen till både Olli och sommaren. Senare framstår denna barndomssommar som en vändpunkt i flera bemärkelser: "Snabbt var sommaren över [...] Skolan ska börja men börjar inte, krig hotar, sen börjar skolan ändå, sen börjar kriget ändå. [...] jag bara tolv när kriget tog slut, som en liten sliten vuxen i barnkläder”. ${ }^{20}$ Sammandrabbningen med Olli får en vidgad betydelse då den följs av oroliga tider och krig. I romanens nutid träffas Benjamin och Olli som nu blivit gamla män; den ena försöker hitta sin identitet genom att söka svar i det förflutna medan den andra är fångad i sitt eget barndomslika gränsland.

Den nämnda beskrivningen av Benjamin vid början och slutet av kriget gestaltar hur han vid den här tiden varit tvungen att gå igenom en plötslig transformation från barn till vuxen. ${ }^{21}$ Trots att förändringen är oåterkallelig, så förblir den delvis ofullständig; med anledning av det han sett och upplevt känner sig Benjamin vuxen, men han är tvungen att tränga in sig i barnets form. Denna konflikt betonas av adjektiven "liten" och "sliten", med vilka Benjamins upplevelse av vuxenhet beskrivs. "Liten" hänvisar till barnets kropp där det vuxna medvetandet är fjättrat, men slitenheten, tröttheten och utmattningen refererar till en vuxen som är ansträngd eller med vilken världen farit hårt fram. På ett sätt som är typiskt för det groteska bildspråket, beskrivs här sida vid sida två kroppar som representerar två olika ytterligheter i livet. ${ }^{22}$ Benjamin, som till sitt medvetande känner sig vuxen men går i barnkläder, kan tolkas som en grotesk hybrid. I det här sammanhanget är det groteska ett drag som beskriver jagberättarens subjektiva upplevelse - ett sätt att förmedla denna erfarenhet till läsaren genom ett bildspråk som utnyttjar det visuella. ${ }^{23}$ Bilden som kombinerar barnets och den vuxnas drag är grotesk framför allt för att båda kategorierna framställs liksom i ett förvrängt ljus. Barnets yttre ger ett uppförstorat intryck och på motsvarande sätt måste det

I9. Ibid., s. 49 .

2o. Ibid., s. 73 .

2I. Metamorfoser behandlas närmare senare i artikeln.

22. Bachtin, Rabelais och skrattets historia, s. 36 .

23. Jfr Perttula, Groteski suomalaisessa kirjallisuudessa, s. 3I. I den subjektiva grotesken anknyter kroppslighet till en skildring av psyket. 
vuxna sinnet tränga sig in i ett alltför litet utrymme. Man kan därtill tolka hybriden mellan barn och vuxen som en referens till en fusion eller sammansmältning mellan den som minns och den som upplever, mellan det berättande och det upplevande jaget, en sammansmältning som äger rum på berättelsens plan. ${ }^{24}$

Även i Carpelans roman Berg (2005) jämförs upplevelsen att se det ur barnets perspektiv obegripliga med att pressa in vuxenheten $\mathrm{i}$ barnets sinne: "jag står med gamla ögon i sommaren, i hämnd. Det doftar som en stor, dödsmärkt kropp, fylld av hat. En ny känsla som är främmande för mig gör sig hemmastadd, som en vuxenkropp i en barnkropp" ${ }^{25}$ Ögonen, som upplevs vara "gamla", refererar till seendet som har en central betydelse i Carpelans produktion. ${ }^{26}$ Den metaforik i Berg som hör ihop med seendet kan ses som ett exempel på hur det bildliga i Carpelans fiktion överförs till ett groteskt modus när det används för att beskriva något som är förträngt eller förvrängt. I Berg återkommer ögonhålorna hos ett lik, en förföljande blick samt en stor gäddas öga som stirrar på barnen från soppskålen. ${ }^{27} \mathrm{I}$ det ovan citerade partiet syns övergången till ett groteskt modus även i miljöskildringen där sommaren förkroppsligas och förvrängs samt blir en dödsmärkt stinkande kropp.

Också i Benjamins bok används miljöskildringen för att betona det traumatiska och avvikande i jagberättarens upplevelse: "Säden står hög och ännu inte skördad, det doftar av lera och blod, det luktar spillning, det stinker av dammiga gölar och avfall; genom allt detta

24. Om det berättande och upplevande jaget ("narrating and experiencing self"), se Dorrit Cohn, Transparent Minds. Narrative Modes for Presenting Consciousness in Fiction, Princeton: Princeton University Press 1978. I min artikel "Between Now and Then. The Representation of Time in Bo Carpelan's Novels Urwind and Berg" (under arbete), studerar jag det berättande och det upplevande jaget i Carpelans romaner samt konstaterar att de två aspekterna av jaget ofta överlappar varandra i romanerna på så sätt att det inte är möjligt eller meningsfullt att skilja dem åt.

25. Bo Carpelan, Berg, Helsingfors: Schildts 2005, s. 55. Liksom i Benjamins bok hänger den personliga skuldkänslan och barndomens konfliktsituationer också i Berg ihop med krigstraumat. Även i romanen Barndom (Bo Carpelan, Barndom, Helsingfors: Schildts 2008) gestaltas krigstidens osäkerhet ur barnets perspektiv genom beskrivningen av hur skolan stängs och hur skolarbetet sedan återupptas.

26. Se Hollsten, Ei kattoa, ei seiniä, s. I9o.

27. Carpelan, Berg, t.ex. s. 6o, 62 och 129. 
går Benjamin”. ${ }^{28}$ Här förstärks den dramatiska stämningen och det groteska i omgivningen av den ännu inte skördade säden som refererar till sommaren. Den oskördade och ännu inte fullmogna säden kan tolkas som en referens till barndomens oskuld, en oskuld som Benjamin ifrågasätter efter att han slagit Olli. Det vackra somriga landskapet med sädesfält visar sig oväntat ha en obehaglig lukt. Benjamin vandrar över fältet som om han vandrade över ett slagfält där han kan känna lukten av blod. ${ }^{29}$

Uppmaningen "Ota Olli", som den vuxna Benjamin hör i drömmen, upprepas flera gånger i verket. ${ }^{30}$ Därför kan läsaren inte undgå den ortografiska och fonetiska likheten med namnet på den groteska fågelgestalten Otaoli som förekommer i romanen. På så sätt framstår fågelgestalten och den groteska metaforik som associeras med denna som en del av bearbetningen av skuldtemat och upplevelsen att barndomen tar slut, som båda är centrala i romanen. I denna fågelgestalt koncentreras de groteska dragen i Benjamins bok. I det följande analyserar jag början av kapitel 65 i romanen, där Otaoli beskrivs för första gången.

\section{INKONGRUENT HYBRIDITET OCH DET VISUELLA}

I kapitel 65 i romanen ges ingen förklarande ram. Jagberättaren beskriver sig själv som barn, liggande i sin säng, vilket gör det möjligt att tolka scenen som en hänvisning till en mardröm han haft i barndomen. Sekvensen i fråga definieras ändå inte explicit som vare sig dröm, inbillning eller hallucination och berättaren tar inte ställning till om den är sann eller inte. Beskrivningen av Otaoli lämnar således

28. Carpelan, Benjamins bok, s. 72.

29. I Merete Mazzarella, Att skriva sin värld. Den finlandssvenska memoartraditionen, Helsingfors: Söderström \& Co I993, s. 38-40, skriver Mazzarella att barndomssommaren, vid sidan om julfirandet, hör till de återkommande motiven i den finlandssvenska memoarlitteraturen, motiv som även är starkt idealiserade. I de verk jag analyserar skriver Carpelan enligt min tolkning emot denna tradition. Att återvända till barndomsminnena framstår hos Carpelan ofta som liktydigt med att bearbeta trauman, snarare än som besök i en idealiserad, nostalgiskt skildrad tid.

30. Uttrycket"Ota Olli" upprepas ordagrant fyra gånger i verket, Carpelan, Benjamins bok, s. 50, 6I, II8 och I40. Därtill finns indirekta referenser till uttrycket på s. 64 och 137 . 
läsaren i osäkerhet och i ett slags mytiskt mellanutrymme som ändå starkt gestaltar jagberättarens upplevelse:

Den onda fågeln står alldeles stilla i människogestalt och vänder sitt blodiga öga mot mig där jag ligger, hoppressad som en mumie i min barnsäng. Där glimmar ett flackande ljus ur bröstkorgen, om fågelns eller min, det vet jag inte, jag har inga vingar, jag slår förgäves med mina kraftlösa klor. Den står vid dörren, den har fjädrar lika grå som gryningen, och den ropar utan att någon annan än jag hör den. Den kommer att riva sönder mig så snart jag rör mig. Den är hämndfågeln, Otaoli heter den, den sveper med sina tjocka vingar in barnen under sin buk och flyger med dem ut över sumpvikar och in i skogar som bara består av rötter, levande armar som sträcker sig efter mig, för jag är förtappad, jag har dödat, jag är mindre än en sten av orörlighet och min mun är fylld av stenens heta ånga. Den onda fågeln liknar en människa, den är klädd i en fotsid dräkt, den talar, den väser, den gurglar som en människa men så tyst att bara de förtappade hör. ${ }^{31}$

I sekvensen som inleder kapitlet betonas en visualitet som utnyttjar skräckens metaforik. I den dramatiska bilden finns en stillastående gestalt som vänder sitt blodiga öga mot sitt förlamade offer. Den bestämda formen, "Den onda fågeln", skapar ett intryck av att det handlar om en specifik gestalt och denna framstår som en visuell symbol för ondska och skräck. I Otaoli kan man se en anknytning till monstren i den klassiska mytologin som kombinerar drag av både människa och djur ${ }^{32}$, särskilt till mytiska fåglar som harpyorna, som har människohuvud och en fågels kropp. Hämndfågeln Otaoli stjäl barn, medan harpyorna för iväg förbrytare för att bestraffas. Bland annat i den ryska sagotraditionen förekommer också fåglar som för bort barn. ${ }^{33}$

Samtidigt som fågel-/människogestalten i sekvensen i Benjamins bok har något bekant över sig, framstår den också som främmande och frånstötande. Gestalten beskrivs med visuella medel, på ett sätt

31. Carpelan, Benjamins bok, s. 87 .

32. Edwards \& Graulund, Grotesque, s. 38.

33. Se exempelvis den ryska folksagan "Gusi-lebedi", finns i finsk översättning under titeln "Hanhi-hanhiset" i Aleksander Lindeberg (toim.), Venäläisiä kansansatuja, Helsinki: WSOY 2008, s. 58-6r. 
som bygger på synintryck, men dess verkliga utseende förblir svårt att gestalta. Å ena sidan är den en fågel, å andra sidan uppträder den i mänsklig gestalt. Först beskrivs gestaltens fjäderdräkt och tjocka vingar. Sedan nämns det däremot att gestalten påminner om en människa: "Den onda fågeln liknar en människa, den är klädd i en fotsid dräkt, den talar, den väser, den gurglar som en människa”. Klädseln och talet bidrar till gestaltens mänsklighet. Verben "väsa" och "gurgla" för däremot tankarna till en orms eller en katts väsande samt till ett för människan otypiskt gurglande läte. Den bild som skapas av Otaoli glider mellan fågelgestalten och dess mänskliga drag, samt överlag mellan det djuriska och det mänskliga. Denna komplexa sammanställning, kombinationen av oförenliga drag och flykten undan bestämda kategoriseringar, styr en mot att tolka gestalten i den groteska estetikens kontext. ${ }^{34}$

I det ovan citerade partiet anknyter Otaolis gestalt på flera sätt till en grotesk tradition i kaysersk mening. Kayser definierar det groteska som en estetik där den mänskliga världen inte framstår som separat från den djuriska, botaniska eller livlösa världen. I det groteska gäller inte de symmetrins och proportionernas lagar som är bekanta från vår värld; exempelvis förvrängs människokroppens proportioner då kroppsdelar sväller, krymper eller deformeras. Denna avsaknad av det trygga och bekanta leder till en upplevelse av främlingskap eller besynnerlighet som i sin tur hänger samman med en hotfull spänning. ${ }^{35}$ Otaoli förenar det mänskliga med det djuriska på ett sätt som därtill bygger på element från nattens och mörkrets sfär, alltså sfärer som ligger utanför den bekanta och trygga världen. Sådana element är exempelvis mumien samt hänvisningar till nattdjur och kräldjur. Även bilder som är hämtade ur skräckens estetik, såsom det blodiga ögat, det flackande ljuset, att slita någon i stycken samt skog som bara består av rötter, betonar den fasansfulla grotesken i kaysersk mening.

Det blodiga ögat, som är en central egenskap hos Otaolis gestalt, får även en djupare betydelse när man betraktar det mot bakgrund av de beröringspunkter som finns mellan Carpelans olika verk beträffande det groteska bildspråket. I Berg uttrycker de groteska ögonen, som är

34. Edwards \& Graulund, Grotesque, s. 2-3.

35. Kayser, The Grotesque in Art and Literature, s. 2I. 
kopplade till seendets motiv, hur en person förföljs av obearbetade negativa känslor. I anslutning till detta kan Otaolis öga ses som en hänvisning särskilt till skuldkänslan, som Benjamin inte kan fly trots att han försöker. Otaolis gestalt och hans blick väcker rädsla och en känsla av hjälplöshet i barnet Benjamin.

Att ligga i sängen "som en mumie" kan tolkas som en bild för att vara förstelnad, förlamad och inte röra sig ur fläcken. Orörligheten kan även tolkas som ett sätt att gömma sig och skydda sig själv, för redan en liten rörelse kunde kanske sätta i gång den händelsekedja vars följd är ett fruktansvärt öde i klorna på den monstruösa fågeln. Paradoxalt nog beskriver jagberättaren också rörelse vid sidan om orörligheten:"jag slår förgäves med mina kraftlösa klor". Slutligen kan läsaren egentligen inte veta vad som händer och vem som rör sig. Då berättaren skildrar lågan eller ljuset som lyser inuti bröstkorgen, kan Benjamin inte längre veta säkert om lågan lyser inuti honom själv eller Otaoli. Att gränsen mellan jaget och en annan gestalt ifrågasätts är en stark beskrivning av att uppleva skräck. Samtidigt tematiserar det en ambivalens och ett uppbrytande av kategoriseringar, som bägge är typiska drag för grotesken. ${ }^{36}$

I beskrivningen av Otaoli hänger jagets problematik även ihop med teman som marginalitet och annanhet då jagberättaren placerar sig själv i Otaolis värld:"den ropar utan att någon annan än jag hör den." De visuella elementens främmandegörande funktion betonas här av en ljudvärld som bygger på motsatsförhållandet mellan tystnad och rop. Otaolis rop skapar en gräns mellan jagberättaren och andra, då ropet hör hemma i en värld som ingen annan kan förnimma. Ropet för in en värdeladdning $i$ texten som är typisk för grotesken. Jagberättaren upplever sig tillhöra de förtappade och placerar således sig själv utanför det normenliga samhället: "för jag är förtappad". Även om uttrycket "någon annan" utgör den enda hänvisningen till en normenlig värld, byggs grotesken upp i relation till en föreställning om det allmänt accepterade, genom en gräns som dras mellan självet och andra, mellan förtappade och icke-förtappade.

36. Om att ifrågasätta gränsen mellan självet och den andra, se Edwards \& Graulund, Grotesque, s. 9 . 
Kaysers definition av det groteska har kritiserats för att den placerar groteskens mörka och skräckinjagande sida i förgrunden så att den sidan rentav framstår som mera genuint grotesk än groteskens uppsluppna och komiska sida. ${ }^{37}$ Chao påpekar att problemet med både Kaysers och Bachtins teori är att de bygger på bara en sida av det groteska. ${ }^{38}$

Trots att kritiken är berättigad, sätter Kayser fingret på något mycket relevant gällande groteskens egenart då han beskriver det groteska som en alienerad värld ${ }^{39}$; även Otaolis fasansfulla, mystiska och samtidigt ambivalenta värld kan tolkas som en sådan alienerad värld.

Även Connelly beskriver det groteska som en främmandegörande strategi: "det groteska kan bäst förstås som något som skapar mening genom att bända upp en klyfta och som drar in oss i en obekant och omtvistad terräng”. ${ }^{40}$ När det gäller Otaoli kan man tolka det så att groteskens djupaste innebörd inte har sitt ursprung i de fasansfulla och monstruösa dragen, även om de genom sin visualitet genast väcker läsarens uppmärksamhet. Om man utgår från Connellys teori finner man de djupast liggande betydelserna då man granskar förändringarna som sker i den groteska bilden, och de specifika partier där det bekanta plötsligt blir främmande. ${ }^{41}$ Redan beskrivningen av Otaoli som en hybrid mellan fågel och människa aktiverar groteskens referensram. I beskrivningen av Otaoli kan kärnan i den groteska bildens betydelse ändå lokaliseras till det ställe i texten där det mänskliga talet överraskande skildras som väsande och gurglande. Det främmandegörande elementet kan sägas undergräva den bild som bygger på fågelmytologi och skräckelement, och som trots den främmandegörande effekten bygger på kulturell återanvändning av bekant bildstoff. När de ickesammanhängande dragen kombineras, skapas en heterogen helhet som inte har någon bekant motsvarighet eller något färdigt namn vare sig i vår verklighet eller i de kulturella metaforer vi känner till. Trots

37. Se t.ex. Bachtin, Rabelais och skrattets historia, s. 55-60 och Chao, Rethinking the Concept of the Grotesque, s. 2-4.

38. Chao, Rethinking the Concept of the Grotesque, s. 2-4.

39. Kayser, The Grotesque in Art and Literature, s. I8r.

40. "the grotesque is best understood as something that creates meaning by prying open a gap, pulling us into unfamiliar, contested terrain", Connelly, The Grotesque in Western Art and Culture, s. 2 [Översättning av citatet till svenska: AB].

4I. Connelly, The Grotesque in Western Art and Culture, s. 3. 
kopplingarna till det mytologiska har Otaoli ingen direkt motsvarighet i de klassiska myternas värld. Gestalten ger inte heller enbart uttryck för skräck. Man kan tolka det så att Otaoli inte främst har sitt ursprung i tidigare kulturellt stoff, utan får sin egentliga betydelse genom gestaltningen av jagberättarens skräck, skuldkänsla och främlingskap. Det är fråga om det groteska i jagets medvetande, om Benjamins upplevelse av skuld och annanhet. På så sätt anknyter romanen, i kaysersk bemärkelse, i hög grad till det subjektiva i grotesken.

Gestalten Otaoli beskrivs med hjälp av kontraster och i den koncentreras flera drag och betydelser med ursprung i olika källor. Enligt min tolkning bygger den ovan citerade sekvensen upp ett tema som är typiskt för det groteska, gränser och gränsöverskridningar. Å ena sidan synliggör de groteska dragen i hög grad gränser, å andra sidan överskrids gränserna. Otaoli kan inte entydigt placeras i någon specifik kategori, utan stannar i gränslandet mellan olika klassificeringar, vilket bryter mot den klarhet och harmoni som är dygder inom den klassiska estetiken. ${ }^{42}$ Sammanfattningsvis kan den groteska hybriditeten i Benjamins bok inte enbart återföras till den visuella inkongruensen utan skapar olika betydelseplan som är sammanvävda med varandra på olika nivåer i texten. I beskrivningarna av Otaoli framstår det groteska särskilt som ett drag i den subjektiva erfarenhetsvärlden. I verket får det groteska ändå en bredare betydelse och förekommer även utanför de skräckens och subjektivitetens områden som har analyserats i detta avsnitt av artikeln. I följande avsnitt lyfter jag fram ställen i texten där gestalten Otaoli också byggs upp av andra element. I relation till ovanstående diskussion skapar dessa element en ambivalens som är karakteristisk för det groteska.

\section{SPÄNNINGEN MELLAN DET SUBJEKTIVA OCH DET OFFENTLIGA}

Otaoli-gestalten, som förekommer upprepade gånger i Benjamins bok, kallas som nämnt för "hämndfågeln" och "den onda fågeln", men

42. Jfr Bachtin, Rabelais och skrattets historia, s. 35; Perttula, Groteski suomalaisessa kirjallisuudessa, s. 32 . 
benämns också "den långa resans fågel" och "höstfågel". ${ }^{43}$ Benämningen "den långa resans fågel" skapar intryck av en ensam flyttfågel eller alternativt ett långvarigt sällskap på resan medan "höstfågel” väcker melankoliska associationer eller för tankarna till uttryck som "livets höst". De benämningar med vilka Otaoli beskrivs, bygger upp de olika sidorna av den groteska gestalten. Inom den rätt heterogena groteskforskningen råder det enligt Chao ändå en viss samstämmighet mellan forskarna kring uppfattningen att grotesken förenar två emotionella aspekter med varandra. Då en av dessa betonas, är ändå den andra samtidigt närvarande. Betoningen kan variera mellan olika konstverk, men i den senaste forskningen har man varit överens om att båda de emotionella aspekterna, groteskens ljusa och mörka sida, på ett eller annat sätt måste vara närvarande för att man ska kunna beskriva något som grotesk. ${ }^{44}$ Otaolis föränderliga gestalt, som vacklar mellan olika känslolägen, byggs upp av splittrade beskrivningar och intryck i olika delar av verket, som betonar olika sidor av gestalten, och som sammantaget, i verket som helhet, skapar det ambivalenta intrycket av Otaoli. I detta avsnitt fokuserar jag särskilt på den spänning som skapas i verket mellan det subjektiva och det offentliga samt mellan det fasansfulla och det karnevalistiska.

Det skratt som vid sidan av skräcken hör till grotesken beskriver Kayser som ett bittert, cyniskt och satiriskt skratt eller som ett oavsiktligt skratt som hänger ihop med känslan av fasa. ${ }^{45}$ Motkraften till den grotesk som väcker fasa, så som den förmedlas i Carpelans verk, tolkar jag ändå inte som ett dylikt reducerat skratt. Men det är heller inte fråga om ett entydigt muntert skratt av den typ som Bachtin lyfter fram som ett centralt element i det groteska. ${ }^{46}$ Emellertid menar jag att Carpelans roman innehåller egenskaper och karnevalistiska drag som hänvisar till en bachtinsk tradition, och som utgör en motkraft till den fasansfulla och förlamande grotesken. Dessa möjliggör spänningen mellan de motsatta emotionella aspekterna. ${ }^{47}$

43. Carpelan, Benjamins bok, s. I5I-I52.

44. Chao, Rethinking the Concept of the Grotesque, s. 4. Jfr Meindl, American Fiction and the Metaphysics of Grotesque, s. I4.

45. Kayser, The Grotesque, s. 187.

46. Bachtin, Rabelais och skrattets historia.

47. Chao och Meindl anser att denna spänning är det som gör det groteska groteskt, 
Tidigt i Benjamins bok skildras Olli innan han blivit handikappad, som en gäckande och livlig gestalt som bryter mot normerna för lämpligt beteende: "När vi körde förbi Halkolas stod Olli där och räckte långnäsa, skrek och viftade med armarna, jag såg inte åt hans håll”. ${ }^{48}$ I detta citat finns flera drag som imiterar en fågelgestalt: att vifta med armarna kan jämföras med att flaxa med vingarna, att räcka långnäsa väcker associationer till en fågels näbb och att skrika kan föra tankarna till en fågels läte. Dylika karikerade drag i beskrivningen av Olli kan tolkas som en grund på vilken Otaolis gestalt byggs upp. De tidigare citerade partierna ur Benjamins bok har lyft fram den sida hos grotesken som har en koppling till skräck. Här hänvisar Ollis gester, såsom att räcka långnäsa, däremot till en muntrare karnevalistisk grotesk. Då Olli uppträder som en fågel förenas i honom det mänskliga och det djuriska, och han framstår som ett slags narr som på offentlig plats tar på sig en roll, samt därigenom får en förevändning att bete sig opassande och göra narr av Benjamin.

Att räcka långnäsa kan också jämföras med att ta på sig ett slags mask. Enligt Bachtin är masken ett motiv som alltid skapar en karnevalistisk stämning i texten, eftersom motivet hänvisar till en annan värld där masken hör hemma. I folkkulturen förknippas masken med förändringar, metamorfoser och glädje över att ta en ny kroppslig form. ${ }^{49}$ Enligt min tolkning hänvisar Ollis "mask" på ett gäckande och förringande sätt till Otaolis värld och till Benjamins skuldkänslor och ångest som denna värld gestaltar. På så sätt har masken som motiv en tragisk och subjektiv sida i Benjamins bok, men i den finns ändå spår av folkkulturens uppochnervända perspektiv, ett perspektiv som driver med Benjamins allvar och dysterhet. Den karnevalistiska tolkningsramen aktiveras redan i det citerade partiet, som förekommer tidigt i romanen, även om det karnevalistiska, då berättelsen fortskrider, är betydligt mera nedtonat och problematiserat i jämförelse med groteskens fasansfulla och subjektiva sida. ${ }^{50}$

och att t.ex. det skrämmande inte är groteskt om det inte samtidigt innehåller något av det uppsluppna, se Chao, Rethinking the Concept of the Grotesque, s. 4; Meindl, American Fiction and the Metaphysis of Grotesque, s. I4.

48. Carpelan, Benjamins bok, s. 34 .

49. Bachtin, Rabelais och skrattets historia, s. 49.

50. Motiv och element som hänvisar till en karnevalistisk tradition, såsom narrmetafo- 
Senare i Benjamins bok beskrivs även Otaoli på ett liknande sätt som Olli, som en rackarunge, en bråkstake som förstör saker: "Fågeln Otaoli som skränar från väggen och bränner hål i gardinerna, jag tar struptag och dränker den i WC-skålen". ${ }^{51}$ Beskrivningen kan tolkas som en referens till Olli i det tidigare citerade partiet eftersom Otaoli, i likhet med honom, utmanar och hånar ordning och gott uppförande. I barndomens möte mellan Olli och Benjamin nöjer sig Benjamin med att se åt ett annat håll och låtsas som om han inte sett Olli. Men i den vuxna Benjamins liv dyker Otaoli däremot upp och gör rackartyg i ett drömlikt ögonblick då Benjamin utmattad kommer tillbaka till sitt hotell efter ett möte med Olli. Och den här gången står Benjamin inte ut med bråkstaken utan tar struptag och dränker Otaoli i wc-skålen. Denna beskrivning kan också jämföras med det tidigare citerade partiet, där orörlighet är Benjamins skyddsmekanism mot det hot som Otaoli utgör. Nu tar Benjamin i stället struptag på den gestalt som speglar hans trauma, vilket kan läsas som att han konfronterar traumat aktivt. Trots detta försvinner Otaoli inte för gott; drunkningsdöden är endast en av gestaltens metamorfoser.

I det här citerade partiet sätts Otaoli, den fasansfulla, mytiska och ställvis rentav upphöjda gestalten, på plats på ett grovt vardagligt sätt. Wc-skålen, där Otaoli dränks, ger beskrivningen en förringande prägel. I den groteska konsten anknyts kroppsligheten med kroppens nedre regioner, dess öppningar, utsöndringar och deformeringar. Bilden av kroppen är inte statisk utan befinner sig i ett konstant och ambivalent förändringstillstånd. I den karnevalistiska traditionen, som särskilt betonar den nyskapande kraften i det groteska, är både den kreerande kroppen och den döende kroppen samtidigt närvarande. De motiv som har sitt ursprung i denna kroppslighetens tradition, såsom födelse, föda, avföring, sex och död, är inte nödvändigtvis groteska i sig själva. I den kulturellt bestämda hierarkin uppfattas de ändå tillhöra ett lägre

ren och en ambivalent framställning av döden, förekommer inte enbart i Benjamins bok utan också i andra prosaverk av Carpelan. Din gestalt bakom dörren (Helsingfors: Schildts 1975) bygger på dubbelgångarmotivet. Karnevalistiska drag, såsom de dödas närvaro, i form av ett kortspelande gäng i barndomens sommarvilla, betonar den groteska ambivalensen i romanen Berg. I Urwind (Helsingfors: Schildts 1993, s. 23I) beskriver jagberättaren en procession av narrar där både levande och döda gestalter deltar, iklädda masker.

51. Carpelan, Benjamins bok, s. I49. 
och materiellt skikt. Det är typiskt för det groteska att degradera och överdriva dessa motiv. ${ }^{52}$ Att döden, via omnämnandet av wc-skålen, förknippas med tarmfunktionen - parallellt med bilden av att strypa någon med bara händerna - betonar det grovt kroppsliga i denna sekvens. Därtill betonas här groteskens funktion att bryta ner den rena skräckkänslan. Skräcken som förknippas med Otaoli utvidgas till en grotesk, vilket framgår tydligt då denna fågelgestalt inte längre skildras som en fasansfull hämndfågel utan som en gäckande bråkstake, som dränks i wc-skålen då den går jagberättaren på nerverna. Vid sidan av skräcken finns också en komisk nyans i denna beskrivning, då den tidigare skildrade förlamande fasan övergår i irritation över Otaolis stökiga beteende.

Den ambivalens som förknippas med Otaoli fördjupas särskilt i en sekvens där jagberättaren ger uttryck för en känsla av samhörighet med denna gestalt: "fågeln Otaoli, min dröm, min uppfinning, han som sitter på min arm som vore jag en falkenerare". ${ }^{53}$ Berättaren ger här också uttryck för sin ensamrätt till Otaoli genom det upprepade possessiva pronomenet "min". I likhet med de andra textställen som nämnts i detta avsnitt kastar det här ett ambivalent ljus över den skräck som hämndfågeln ger upphov till; Otaoli kan inte entydigt placeras i skräckens, det ondas eller den typiska mardrömmens kategori, utan befinner sig i ett gränsland mellan olika kategorier, vilket väcker förvirring hos läsaren. Intressant i det senast citerade partiet är också hur jagberättaren karakteriserar fågeln som en produkt av sitt subjektiva medvetande. Berättaren hänvisar samtidigt till Otaoli som en medveten "uppfinning" och en mera undermedveten "dröm". Ambivalensen förstärks även av kopplingen till mytiska falkar, som till skillnad från de tidigare nämnda skräckfåglarna, förknippas med gudomliga gestalter i såväl den fornegyptiska som den skandinaviska mytologin. Otaoli väcker sinsemellan motstridiga känslor hos läsaren,

52. Bachtin, Rabelais och skrattets historia, s. 29-36.

53. Carpelan, Benjamins bok, s. I7r. Utdraget kan även tolkas som en hänvisning till novellen "Federigo degli Alberighi och hans falk" i Giovanni Boccaccios Decamerone (I350-I353), (femte dagen, novell IX) där en falk, som är viktig för karaktären i berättelsen, offras och serveras till middag. Giovanni Boccaccio, Decamerone, Del I, Översättning, inledning och kommentarer av Paul Enoksson, Stockholm: Atlantis 2007, s. 468-474. 
skräck, skratt, avoghet, tillgivenhet och respekt. På ett sätt som är typiskt för groteska gestalter utmanar Otaoli alltså läsaren genom att aktivera olika känslor och reaktioner parallellt med varandra. ${ }^{54}$

\section{METAMORFOSEN - RÖRELSEN MELLAN OLIKA SKEPNADER OCH KÄNSLOL ̈̈GEN}

Det mångdimensionella i Otaolis gestalt betonas ytterligare genom beskrivningarna av de metamorfoser Otaoli genomgår. Den groteska fågelgestalten i Benjamins bok är inte statisk utan tar olika former och förändras till sin yttre gestalt. De olika yttre gestalterna betonar sinsemellan olika betydelser. I kapitel 65 i romanen framställs Otaoli först som en skräckfågel som väcker fasa. Mot slutet av kapitlet betonas ändå den kontinuerliga rörelse som är typisk för den groteska gestaltens metamorfos, då Otaolis transformation från hämndfågel med blodiga ögon till en pytteliten insekt framställs för läsaren:

Den glider i lerskogarna som en skugga, stannar bakom gardinen vid fönstret, förminskar sig till ett svart kryp, rinner ut genom glaset som ett ögonblick färgas svart, bara en sotränna med en näbb som en gul tumnagel, ögat nu slutet, kroppen nu borta, Otaoli nedgrävd, drunknad, upphängd, bara en vit bröstkorg med några grå fjädrar oroligt flimrande för morgonvinden. ${ }^{55}$

Efter att ha krympt rinner Otaoli ut genom fönsterglaset och försvinner. Förutom en förminskning handlar det alltså om en metamorfos från materiell och kroppslig gestalt till ett slags immateriellt rudiment av den tidigare gestalten. I detta utdrag tematiseras Otaolis rörelse inifrån en inomhusmiljö utåt till en utomhusmiljö. Enligt min tolkning kan detta ses som en parallell till det subjektiva i den fasa som Otaoli ger upphov till. I den värld som jagberättaren konstruerar i sitt medvetande flyger Otaoli hotfullt omkring, men utanför medvetandet framstår den bara som ett rudiment av den gestalt som väcker fasa och förlamar sitt offer. Av den ståtliga fjäderskruden återstår inte mer

54. Jfr Perttula, Groteski suomalaisessa kirjallisuudessa, s. 18, 27-28.

55. Carpelan, Benjamins bok, s. 87. 
än en sotränna, av näbben endast en liten gul fläck och det blodiga ögat är slutet.

I utdraget skildras Otaoli dessutom som om den var flerfaldigt död(ad): begravd, drunknad, hängd ("upphängd"). Den bröstkorg som återstår, där några ynkliga fjädrar sitter kvar på de vita benpiporna, hänvisar även till det tidigare citerade utdraget där ett mystiskt ljus skiner ur den skräckinjagande Otaolis bröstkorg. Endast ett bart skal återstår nu av denna skräckens kärna. Även nattens mardrömmar har ersatts av morgonvinden, och ingen blir längre skrämd av de enstaka gråa fjädrarna som fladdrar i luftströmmen. Den skräck som Otaoli väcker tål alltså inte dagsljus. Fågelgestalten försvinner ändå inte, den bara ändrar form och genomgår ytterligare nya metamorfoser.

Enligt Bachtin skildrar den groteska bilden ett förändringstillstånd som ännu inte fullbordats. Typiskt handlar det om en metamorfos som hänger ihop med födelse, död eller uppväxt, där relationen till tiden blir synlig. I bilden av den groteska kroppen är förändringens båda sidor, början och slutet, samtidigt närvarande. Det är i detta man finner rötterna till den ambivalens som oupplösligt hör ihop med det groteska. I sin motstridighet är den groteska bilden ständigt rörlig och föränderlig till sin karaktär, vilket skiljer den från den stabila och avstannade bilden som är typisk för den klassiska estetiken. ${ }^{56}$

När en människas eller annan varelses metamorfos inte är fullständig, blir resultatet en grotesk och hybrid. I den metamorfos som är karakteristisk för det groteska bildspråket bevaras en del av de ursprungliga egenskaperna, vilket gör att exempelvis varelsens förändrade yttre uppenbarelse kan stå i konflikt med dennas oförändrade inre. ${ }^{57}$ På motsvarande sätt kan man se bilden av en vuxen i barnkläder, "en liten sliten vuxen", som en bild av en ofullständig metamorfos och en snedvriden uppväxt. I denna bild sker rörelsen och förändringen ändå inuti karaktären, i dennas erfarenhet, medan den yttre uppenbarelsen representerar det stagnerade tillståndet som inte motsvarar den inre erfarenheten. Otaolis metamorfoser kan tolkas som upprepningar av jagberättarens upplevelse av att barndomen tog slut och av att fastna i ett mellantillstånd. I beskrivningen av denna erfarenhet bygger upp-

56. Bachtin, Rabelais och skrattets historia, s. 34-35.

57. Perttula, Groteski suomalaisessa kirjallisuudessa, s. 75-76. 
repningen och variationerna av metamorfosmotivet upp en struktur som är typisk för traumat.

Enligt Kai Mikkonen som undersökt metamorfosen i litteratur kan man se denna bildlighet som en tidslig och dynamisk process som bygger på såväl likhetens som parallellitetens principer. ${ }^{58}$ Sålunda kombinerar den drag som är typiska för dels metaforen, dels metonymin. Relationen mellan Otaoli och jagberättarens erfarenhet kan mycket riktigt också uppfattas som metaforisk. Exempelvis Chao har i sin forskning definierat grotesken som en förkroppsligad metafor som ger upphov till osäkerhet och disharmoni och som flyr undan exakta definitioner. ${ }^{59}$ Man kan tolka det så att Otaoli, som en metafor för jagberättarens erfarenhet, ger en visuell och kroppslig gestalt åt de svårverbaliserade upplevelserna. Det ofullbordade och ofullständiga, som är typiskt för de metamorfoser som förekommer i den groteska bilden, framställs för sin del metonymiskt. Då hämndfågeln Otaoli rinner ut genom fönsterglaset och förvandlas till ett rudiment av sin tidigare gestalt förs metamorfosen mycket långt; Otaoli blir nästan immateriell. I fläckarna på fönsterglaset kan man ändå urskilja en mörk färg och en reminiscens av den gula näbben. Tillståndet före transformationen kan liksom konstrueras mentalt med hjälp av delar som hänvisar till den tidigare hela gestalten. I sin egenskap av en kvarbliven del representerar skelettet av bröstkorgen, som beskrivs i slutet av utdraget, likaså den hela gestalten Otaoli som fanns före transformationen.

Med utgångspunkt i min analys kan man konstatera att Otaolis metonymiska drag betonar att transformationen är ofullständig och att Otaoli vacklar mellan olika kategorier på ett sätt som är karakteristiskt för den groteska bilden. Genom att framställa två företeelser parallellt med varandra, på ett sätt som är typiskt för metaforen, framstår denna gestalt emellertid som en metafor för jagberättarens subjektiva erfarenhet och samtidigt även som en bild för de minnen som är associerade med Olli och som kontinuerligt försöker tränga fram ur det undermedvetna. Som metafor gestaltar Otaoli således känslor som

58. Kai Mikkonen, The Writer's Metamorphosis. Tropes of Literary Reflection and Revision, Tampere: Tampere University Press 1997, s. 27-28.

59. Chao, Rethinking the Concept of the Grotesque, s. I4. 
i romanen är sammanvävda med varandra: skuld, annanhet och en skräck som orsakats av kriget. Att befinna sig mitt emellan kategorier, att växla yttre gestalt och att vackla mellan olika sinnesstämningar är karakteristiskt för den groteska estetiken men anknyter också till den carpelanska öppenhetens poetik som flyr undan klassificeringar och kategoriseringar.

\section{UPPBRYTNING AV MOTSATSER OCH DEN ÖPPNA STRUKTUREN}

Inkongruenta kombinationer, konstant rörelse och den osäkerhet som är en följd av ambivalens är alltså typiska för det groteska. Edwards och Graulund påpekar emellertid att grotesken inte bör förstås som osäkerhet för osäkerhetens skull: "Genom att erkänna den osäkerhet som är central i groteska texter, förblir vi öppna, multipla, och som sådana kan vi omfamna osäkerheten hellre än säkerheten; och detta i sin tur står emot totalisering i alla dess former och erbjuder många vägar till mångbottnade läsningar”. ${ }^{60}$ Den osäkerhet som grotesken ger upphov till representerar alltså en möjlighet till en öppen struktur som inte strävar efter säkerhet eller definitiva klassificeringar. De metamorfoser som analyserades i föregående avsnitt kan tolkas som beskrivande exempel på denna öppenhet och på det ofullbordade. Ur detta perspektiv kan grotesken förstås som en systematisk process vars syfte är att främja en känsla av att inte höra till. ${ }^{61}$

I den helhet som Benjamins bok utgör formar de mångdimensionella skildringarna av Otaoli en öppen struktur. Gestaltens olika drag, emotionella aspekter och föränderliga rörlighet betonar att här finns flera parallella tolkningsmöjligheter snarare än absoluta kategorier. Ett utdrag mot slutet av verket kan tolkas som en kulmination för inkongruenta och motsatta drag, där spänningen mellan dessa upplöses. På sin resa märker Benjamin att Olli har åldrats men Ollis

6o. "For by acknowledging the lack of certainty at the heart of grotesque texts, we remain open, multiple, and, as such, we can embrace uncertainty over certainty; this, then, resists totalization, in all its forms, and offers many routes into multiple readings", Edwards \& Graulund, Grotesque, s. 3 [Översättning av citatet till svenska: $\mathrm{AB}]$.

6r. Edwards \& Graulund, Grotesque, s. 3. 
medvetande befinner sig på ett barns nivå och han är innesluten i sig själv. Även Olli reagerar starkt på mötet och springer sin väg mitt under en gemensam promenad för att slutligen stanna upp:

Och sedan stannar han upp, gamle man, skriker mot måsarna som cirklar i vikbottnet, ett gällt skrik, som var han en av de fria fåglarna eller en plågad, insnärjd, eller båda på en gång, hans skrik kom landskapet att darra, ekot breder sig som väldiga vingar av eld över fälten och ut mot skogen, en fågel Otaoli brinnande och slocknande när regnet börjar falla. ${ }^{62}$

I början av utdraget förenas människa och fågel i en jämförelse som beskriver Olli. Det fågelliknande har här ingen entydig betydelse, utan jämställs både med frihet och med att vara plågad och fången. Samtidigt konstrueras ett motsatsförhållande mellan den frigörande luften och jorden som står för bundenhet och fångenskap. Dessa två extremer förbinds dessutom med varandra och gestaltar ytterligare ett alternativt sätt att vara: "båda på en gång”. Efter detta utvecklas Ollis fågelliknande drag i en mera mytisk riktning. Proportionerna i Ollis skrik utvidgas från en stackars mans skrän till en enorm varelses läte som får marken att skälva. I utdraget transformeras ljudet eller dess eko och tar en visuell form då Otaoli slutligen visar sig som en enorm fågel med vingar av eld. Jämsides med det bombastiskt mytiska och eldens element skildras vattnet, vilket skapar en ambivalens i beskrivningen. Utdraget kan tolkas som en form av katharsis där motsättningar och gränser mellan olika kategorier upphävs. I mötet mellan alla fyra element är det slutligen vattnet som släcker och lugnar ner den brand som representerar det hotfulla och fasansfulla i Otaoli. Beskrivningen kan också tolkas som en hänvisning till myten om Fågel Fenix som betonar förnyelse och odödlighet, vilket även knyter an till de metamorfoser som analyserades ovan. Sekvensen tycks också förebåda slutet av romanen där Olli dör efter att ha rymt hemifrån. Benjamin uppnår för sin del någon form av inre harmoni och förföljs inte längre av Otaoli.

62. Carpelan, Benjamins bok, s. I54. 
Analysen av den öppna struktur som grotesken möjliggör väcker frågan i vilken relation detta står till den öppenhetens poetik som Carpelan fört fram. På ett sätt som påminner om den öppenhet som är typisk för det groteska, ser även Carpelan osäkerheten som ett centralt element i processen att uppnå öppenhet. Han beskriver konstnärens negativa förmåga som en konst att transformera osäkerhet, tvivel och passivitet till en positiv energi. Även att upphäva motsättningar är av central betydelse:

På samma sätt som den negativa förmågans, den skenbara passivitetens förmåga består i att med stor öppenhet reflektera över tillvarons motsatser och betvivla de hårdragna gränserna mellan en klassisk och romantisk målsättning, betvivlar den även hierarkin av förflutet, nu och kommande, och samlar alla tidsupplevelser i det omedelbara ögonblicket. ${ }^{63}$

Enligt min tolkning hänvisar den öppenhet som är karakteristisk för den groteska estetiken delvis till samma fenomen som Carpelan syftar på i sitt öppenhetsbegrepp. De gränsöverskridande dragen i grotesken, som på flera sätt varit framträdande i min analys av Benjamins bok, utgör ett ideal också i öppenhetens poetik så som Carpelan definierar den. Även Carpelans poetik flyr strikt avgränsade kategorier och klassificeringar samt slutgiltiga svar och statiska, slutgiltiga tillstånd. Begrepp som transgression och gränsöverskridande ger ändå inte en uttömmande beskrivning av idealet för Carpelans öppna diktning. Karakteristiskt för öppenhetens poetik är även spänningen mellan öppenhet och det samlande eller obrutna. Den kommer till uttryck exempelvis i ett kort ögonblick som samlar alla tidsupplevelser, vilket blir möjligt då hierarkin mellan olika tidsplan upphävs. Enligt Hollsten är öppenheten alltså inte en motsatt tendens i jämförelse med det samlande, utan det obrutna nås genom öppenhet. ${ }^{64}$ Trots all problematisering av slutliga klassificeringar eftersträvar Carpelans öppenhet alltså i slutändan harmoni, medan grotesken däremot gör motstånd mot harmoni och den naturliga ordningen. Öppenhetens

63. Carpelan,"Om diktens öppenhet".

64. Hollsten, Ei kattoa, ei seiniä, s. I32. 
poetik innebär en balans mellan estetiska och filosofiska drag med olika ursprung, medan grotesken bygger på motstånd mot den klassiska estetiken.

Det är heller inte en rättvis bild av grotesken, betraktad som ett bredare, estetiskt och kulturellt fenomen, om man enbart återför den till begrepp som transgression och metamorfos eller till den hybriditet som ifrågasätter fasta kategorier. Det är skäl att beakta att grotesken i typiska fall lyfter fram undanträngt subjektivt eller kulturellt stoff. ${ }^{65}$ I de tidigare avsnitten har jag analyserat hur denna, för grotesken karakteristiska moraliska dimension syns i den subjektiva skuldkänsla som har sitt ursprung i Benjamins barndom. I verket behandlas emellertid också, med hjälp av grotesken, teman som avvikelse och marginalitet på ett bredare plan. Detta sker genom en problematisering av kategorierna sjuk och frisk. Olli, en individ som avviker från den friska människans norm, väcker följande reflexioner hos Benjamin: "kanske gränsen mellan vad vi kallar friskt och sjukt inte kan dras, kanske går friskt och sjukt in i varandra." ${ }^{66}$

Hur öppenhetens poetik och grotesken är sammanvävda med varandra i Benjamins bok kan tydligast åskådliggöras genom att se på hur groteskens moraliska dimension anknyts till det slags reflexion över begreppsdefinitioner som är typisk för Carpelans essäistik. Det är exempelvis intressant att studera Benjamins funderingar över gränsen mellan frisk och sjuk jämsides med Carpelans filosofiska sammanfattning i en diskussion kring det öppna rummet: "Kanske tid och rum alls inte är varandras antagonister, utan genomsyrar varandra?" ${ }^{67} \mathrm{I}$ båda fallen tematiseras ett upphävande av gränsen mellan två kategorier som uppfattas som varandras motsatser, samt en strävan efter en syntes mellan dessa. Detsamma gestaltas också i skildringen av Olli som en både fri och fången fågel. På så sätt hänger öppenhetens poetik och grotesken samman i Benjamins bok, genom dels upphävandet av motsättningar, som är ett uttryck för öppenhet, dels en för grotesken karakteristisk problematisering av kategoriserande normer. ${ }^{68}$

65. Edwards \& Graulund, Grotesque, s. 6.

66. Carpelan, Benjamins bok, s. I50.

67. Bo Carpelan, "I poesins rum", Hufoudstadsbladet 25/4 I99I.

68. Också i min artikel "Muistojen arkisto ja muistelun kertomus. Muuntuva arkistometafora Bo Carpelanin romaanissa Blad ur höstens arkiv"[under arbete] konstaterar 
Jag hävdar att grotesken i Benjamins bok är sammanvävd med öppenhetens poetik samt utgör en strategi med vilken denna poetik kommer till uttryck i romanen. Med hjälp av grotesken behandlas sådant som är undanträngt $i$ kulturen och på ett subjektivt plan, samt teman som avvikelse och marginalitet. De beröringspunkter med Carpelans övriga prosaverk som jag visat på i artikeln väcker frågan om grotesken är en estetik som mera genomgående återkommer i Carpelans prosa, en fråga som återstår att behandla i den framtida forskningen.

Översättning: Anna Biström

jag att upphävandet och ifrågasättandet av gränsen mellan olika kategorier är typiska drag i Carpelans litterära stil. Artikeln kommer ut 2018 i antologin How to Communicate Meaning? Linguistic, Literary, and Translational Perspectives (publikationen är under kollegial granskning), som utges av forskningscentret Plural vid Tammerfors universitet, i serien Tampere Studies in Language, Translation and Literature. 